\title{
Neutral point clamped quasi $Z$ source inverter for photovoltaic systems
}

\author{
M. Aravindan', V. Balaji ${ }^{2}$, V. Saravanan ${ }^{3}$, M. Arumugam ${ }^{4}$ \\ ${ }^{1}$ Department of Electrical and Electronics Engineering, Sri Chandrasekarendra Saraswathi Viswa Maha Vidyalaya \\ (SCSVMV) University, India \\ ${ }^{2}$ School of Electrical Engineering, Bahir Dar University, Ethiopia \\ ${ }^{3,4}$ Department of Electrical and Electronics Engineering, Arunai Engineering College, India
}

\begin{tabular}{l}
\hline \hline Article Info \\
\hline Article history: \\
Received Jan 17, 2019 \\
Revised Mar 6, 2019 \\
Accepted Apr 20, 2019
\end{tabular}

Keywords:

Photovoltaic systems

Reduced component stress

Three level neutral point quasi

$\mathrm{Z}$ source inverter

Voltage boosting ability

\begin{abstract}
Multilevel inverters are becoming popular for power conversion in renewable energy systems, AC-DC hybrid micro grids etc. The voltage stress and inrush current through these inverter leg switches are quite higher as compared to the load ratings which increase the chances of inverter leg switch failure. A three level neutral point clamped quasi $\mathrm{Z}$ source inverter topology is discussed in this paper which has the features of lower component count, reduced capacitor voltage stress, and it can be operated at different control strategies to achieve wide range of voltage boosting ability, suited for photovoltaic (PV) systems. It also ensures continuous input current irrespective of the DC supply voltage variations and injects stable and smooth power to the load/grid. The effectiveness of the proposed inverter is verified by simulation results in MATLAB Simulink model as well as performing experiment with the help of a laboratory prototype.
\end{abstract}

Copyright (ㅇ 2019 Institute of Advanced Engineering and Science. All rights reserved.

\section{Corresponding Author:}

V. Saravanan,

Departement of Electrical and Electronics Engineering,

Arunai Engineering College,

Tiruvannamalai 606 603, Tamilnadu, India.

Email: vsaranaec@yahoo.co.in

\section{INTRODUCTION}

Latest advances in solar technology and developments in power electronics offers a cost effective photovoltaic (PV) power generation for meeting electric requirement of the country. Also, strategic and supportive government incentives and tariff schemes are contributing to the wide spread usage and promotion of PV power systems. Multilevel inverter produce an output voltage that is always lower than the total dc source voltage, which is not desired for interfacing renewable sources like PV systems. The harmonic losses produced by these inverters are low, and the waveform quality will be better at higher modulation ratio. Neutral point clamped (NPC) topology is one of the most well known type of multilevel inverters and is widely spread in the market for various industrial applications. NPC inverter has a common DC bus for three phases that makes it suitable for stand alone and grid connected applications where a renewable energy resource should be used and there are limits on the number of isolated DC supplies [1-3].

Multilevel voltage source inverter (MVSI) have advantages like improvement in waveform quality, lower generated common mode voltage, lower voltage stress across semiconductors, reduced switching losses, better harmonic performance, reduced electromagnetic interference suited for high power applications [4-5]. However, MVSI may produce increased output voltage with the aid of expensive and bulky transformers (which increases the system size and weight) or by the use of dc-dc boost converters (number of power converter stages increases system control complexity and decreases the system efficiency). In MVSI, shoot through (i.e. switching all the switches in the inverter leg) results dead short circuit of the source. Shoot 
through is avoided by providing dead band between switching control signal fed to the complementary switches of inverter leg, which introduces distortion in the output AC voltage. This situation can be overcome by the use of Z source inverter (ZSI) which has the features of both buck and boost abilities, to achieve the required $\mathrm{AC}$ voltage in a single stage, suited for various applications like renewable energy systems and electric vehicles etc.

ZSI is constructed by simply inserting a X shaped LC impedance network between the input dc source (from PV system) and inverter bridge. The impedance network, comprising symmetrically placed passive components viz inductors and capacitors, serves mainly to accumulate inductive energy during unique shoot through interval before releasing that energy for boosting the inverter output voltage in the remaining duration of a switching period. Variants in ZSI are developed by various researchers over the years [6-8]. Quasi ZSI is an improved derivative of ZSI which maintains continuous input current, less voltage stress across the switching component, and have reduced passive component ratings. $\mathrm{Z}$ source energy conversion technique to various inverters has been worked out with different modulation schemes with LCL filter are reported in $[9,10]$. Selection of power semiconductor devices influence the efficiency of the designed inverter system with conduction losses, low switching and self discharge losses at optimal switching speed, effectiveness in terms of device failure as reported in [11-13].

Combining the features and properties discussed above, a three level single phase neutral point clamped (NPC) quasi Z Source inverter which utilises two basic quasi Z source impedance networks in a symmetrical fashion has been worked out in [14]. This NPC quasi ZSI utilizes four inductors, four capacitors and two diodes in the intermediate network for single stage boost mode of operation as well as to give a three level AC output.The overall efficiency of the photovoltaic system depends on selected inverter topology and employed modulation scheme together with loss mechanisms and grid codes as defined by IEEE/IEC standards.

In this paper, a three phase three level neutral point clamped quasi $\mathrm{Z}$ source inverter $(3 \mathrm{P} / 3 \mathrm{~L} \mathrm{NPC}$ qZSI) is proposed. It is a combination of quasi $\mathrm{Z}$ source network and three level neutral point clamped inverter. It can evenly distribute losses among switching devices by selecting the upper or lower NPC paths, leading to a substantial increase in the inverter output power. It can buck and boost the input dc voltage with short circuit immunity and possess high energy density.3P/3L NPC qZSI consists of two quasi Z (qZS) network which contains 4 inductors $\left(\mathrm{L}_{1}-\mathrm{L}_{4}\right), 4$ capacitors $\left(\mathrm{C}_{1}-\mathrm{C}_{4}\right)$ to boost the input dc voltage to a higher dc voltage with reduced $\mathrm{Z}$ source network capacitor voltage stress and also inhibit the starting inrush current. The power circuit of 3P/3L NPC qZSI consists of 12 switches, 6 clamping diodes and 2 balancing capacitors $\left(\mathrm{C}_{\mathrm{b} 1}\right.$ and $\left.\mathrm{C}_{\mathrm{b} 2}\right)$ are connected with single DC source energised preferably photovoltaic system. Rest of the paper is organized as follows. Operational analysis of the proposed inverter topology with mathematical validation is presented in section 2, Simulation and experimental results are discussed in section 3 and 4 respectively and paper is ended with a conclusion in section 5 .

\section{OPERATIONAL ANALYSIS OF THE PROPOSED TOPOLOGY}

The general circuit of 3P/3L NPC qZSI is shown in Figure 1. The input DC source realized from PV system can be splitted into two dc sources by connecting two series connected capacitors. By employing qZS network, combined dc voltage is boosted up and fed into the NPC circuitry which allows the inverter to produce three distinct voltage levels corresponding to each phase leg. It has advantages such as continuous input current, lower voltage stress across semiconductors, lower voltage blocking capability, decreased $\mathrm{d} v / \mathrm{dt}$, operates at higher switching frequency due to lower switching losses, possibility to use shoot through, balanced neutral point voltage, reduced capacitor voltage stress, inherent inrush current limitation and better harmonic performance. It has better elimination capability of common mode leakage current, so no additional common mode filters are required. Due to the above features, this inverter is especially suitable for PV systems, where superior harmonic performance and ability to support independent maximum power point tracking is required.

The schematic of three phase three level neutral point clamped inverter (3P/3L NPC inverter) is shown in Figure 2. It contains four switches $\left(\mathrm{S}_{\mathrm{X} 1}, \mathrm{~S}_{\mathrm{X} 2}, \mathrm{~S}_{\mathrm{X} 3}, \mathrm{~S}_{\mathrm{X} 4}\right.$, ) in each leg $(\mathrm{X}=\mathrm{A}, \mathrm{B}$ and $\mathrm{C})$ and two diodes $\left(\mathrm{D}_{\mathrm{X} 1}, \mathrm{D}_{\mathrm{X} 2}\right)$ clamped to the midpoint of capacitors $(\mathrm{X}=\mathrm{A}, \mathrm{B}$ and $\mathrm{C})$. For phase $\mathrm{A}$, gating signals of switches $\mathrm{S}_{\mathrm{A} 3}$ and $\mathrm{S}_{\mathrm{A} 4}$ are in complementary to $\mathrm{S}_{\mathrm{A} 1}$ and $\mathrm{S}_{\mathrm{A} 2}$, which is the same in other remaining legs. Hence, there are just two separate pulses to command those four switches for each phase leg. Each branch of the inverter has three output voltage levels: $0 \pm \mathrm{V}_{\mathrm{dc}} / 2$, where $\mathrm{V}_{\mathrm{dc}}$ is peak of the $\mathrm{dc}$ link voltage. The clamped diodes are used to produce zero voltage. The operating period of 3P/3L NPC qZSI is divided into several time intervals. Due to quasi $\mathrm{Z}$ source (qZS) network, another shoot through state is added when all the switches are conducting. During this state, energy is accumulated in inductors and is transferred to capacitors and output load within other states. As a result, $\mathrm{V}_{\mathrm{dc}}$ is regulated only by adjusting the shoot through duty cycle. 


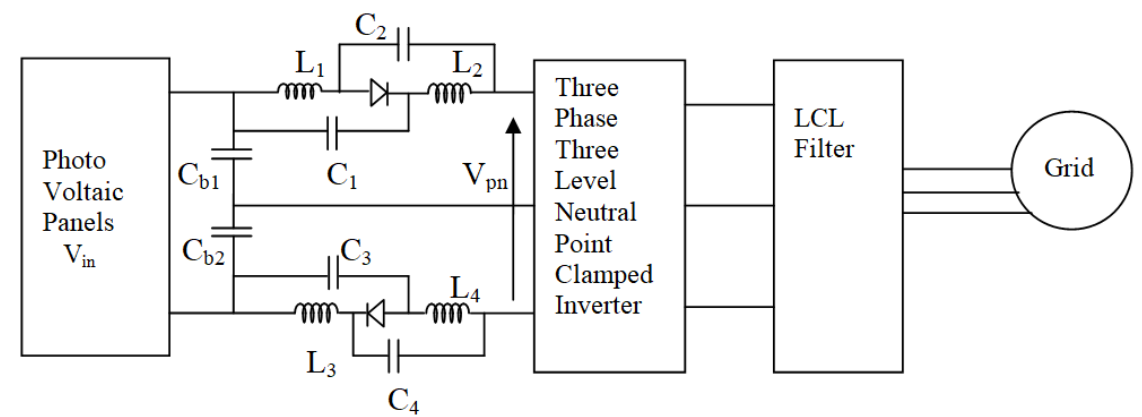

Figure 1. Three phase three level neutral point clamped quasi $\mathrm{Z}$ source inverter

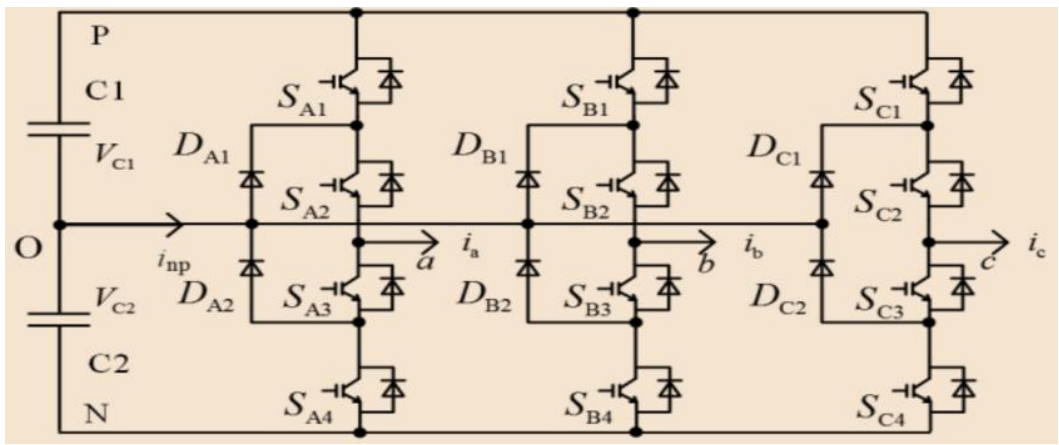

Figure 2. Circuit schematic of three phase three level neutral point clamped inverter

The behavior of qZS network can be represented by means of three equivalent circuits shown in Figure 3. Accordingly, all the switching states can be separated into three main modes: zero state as shown in Figure 3(a), active states as shown in Figure 3(b) and shoot-through state as shown in Figure 3(c) that can be applied within the zero state.

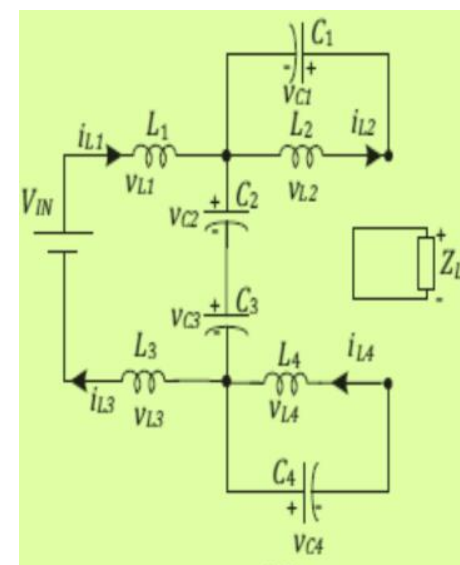

(a)

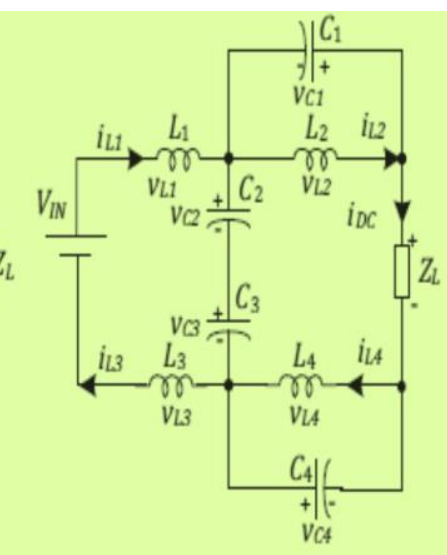

(b)

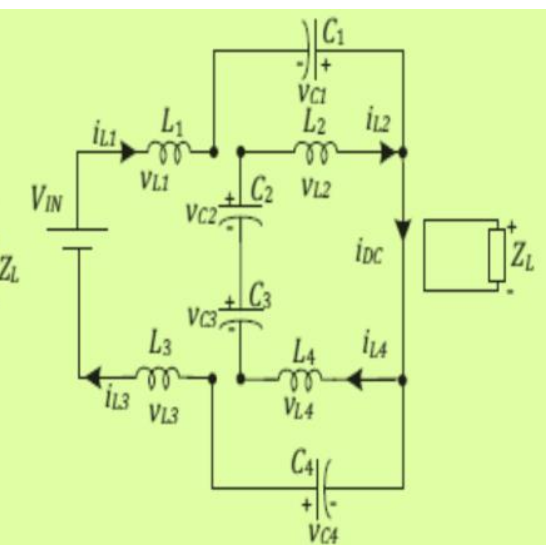

(c)

Figure 3. Equivalent circuits of 3P 3L-NPC qZSI: (a) zero state, (b) active state, (c) shoot-through state

Assuming that $\mathrm{L}_{1}=\mathrm{L}_{2}=\mathrm{L}_{3}=\mathrm{L}_{4}=\mathrm{L}, \mathrm{C}_{1}=\mathrm{C}_{2}=\mathrm{C}_{3}=\mathrm{C}_{4}=\mathrm{C}$, and the topology is symmetrical, following equations are realized $[15,16]$.

$$
V_{L 1}=V_{L 2}=V_{L 3}=V_{L 4}=V_{L}
$$


$V c_{1}=V c_{2}=V c_{3}=V c_{4}=V c$

$V c=\frac{D_{o} V_{\mathrm{dc}}}{2\left(1-2 D_{o}\right)}$

Where $D_{o}$ is the shoot-through duty ratio,

$$
D_{o}=\mathrm{T}_{\mathrm{o}} / \mathrm{T}_{\mathrm{s}}
$$

The peak output phase voltage can be expressed as:

$$
\text { Vout }=\frac{M V_{\mathrm{dc}}}{2\left(1-2 D_{o}\right)}=M B \frac{V_{\mathrm{dc}}}{2}
$$

where $\mathrm{M}$ is the modulation index, $\mathrm{B}$ is the boost factor

$$
B=\frac{V_{d c}}{V_{\text {in }}}=\frac{V_{c 1}+V_{c 2}+V_{c 3}+V_{c 4}}{V_{\text {in }}}=\frac{1}{\left(1-2 D_{o}\right)}
$$

The output $\mathrm{AC}$ voltage in the three phases is given by:

$$
\left[\begin{array}{l}
V_{a o} \\
V_{b o} \\
V_{c o}
\end{array}\right]=\left[\begin{array}{ll}
S_{a 2} & S_{a 1} \\
S_{b 2} & S_{b 1} \\
S_{c 2} & S_{c 1}
\end{array}\right]\left[\begin{array}{c}
V_{c 1}+V_{c 2} \\
V_{c 2}
\end{array}\right]
$$

where $\mathrm{V}_{\mathrm{ao}}, \mathrm{V}_{\mathrm{bo}}$ and $\mathrm{V}_{\text {co }}$ are inverter output voltages referenced to the point $\mathrm{o}$ (as depicted on the negative side of DC link). $\mathrm{V}_{\mathrm{C} 1}$ and $\mathrm{V}_{\mathrm{C} 2}$ are $\mathrm{DC}$ capacitor's voltages, respectively. $\mathrm{T}_{\mathrm{i} 0-2}$ denotes the triggering functions associated to each inverter leg $(\mathrm{i}=\mathrm{a}, \mathrm{b}, \mathrm{c})$ and it can be defined as:

$$
\begin{aligned}
\mathrm{T}_{0 \mathrm{i}} & =\left\{\begin{array}{ll}
1, & \text { if switching case } 0\left(\mathrm{~S}_{\mathrm{i} 3} \text { and } \mathrm{S}_{\mathrm{i} 4} \text { are } \mathrm{ON}\right) \\
0, & \text { other switching cases }
\end{array}\right\} \\
\mathrm{T}_{\mathrm{i} 1} & =\left\{\begin{array}{ll}
1, & \text { if switching case } 1\left(\mathrm{~S}_{\mathrm{i} 2} \text { and } \mathrm{S}_{\mathrm{i} 3} \text { are } \mathrm{ON}\right) \\
0, & \text { other switching cases }
\end{array}\right\} \\
\mathrm{T}_{\mathrm{i} 2} & =\left\{\begin{array}{ll}
1, & \text { if switching case } 2\left(\mathrm{~S}_{\mathrm{i} 1} \text { and } \mathrm{S}_{\mathrm{i} 2} \text { are } \mathrm{ON}\right) \\
0, & \text { other switching cases }
\end{array}\right\}
\end{aligned}
$$

Using these switching functions, the currents relations can be derived:

$$
\left[\begin{array}{c}
i_{o} \\
i_{1} \\
i_{2}
\end{array}\right]=\left[\begin{array}{ccc}
S_{a 0} & S_{b o} & S_{c o} \\
S_{a 1} & S_{b 1} & S_{c 1} \\
S_{a 2} & S_{b 2} & S_{c 2}
\end{array}\right]\left[\begin{array}{c}
i_{a} \\
i_{b} \\
i_{c}
\end{array}\right]
$$

Exhaustive research work have been done in developing various modulation techniques like carrier based pulse width modulation (CB PWM), space vector pulse width modulation (SVPWM), phase shift PWM, selective harmonic elimination PWM, nearest level modulation for NPC inverter with the feature of neutral point potential balancing at low switching frequencies are discussed [17-36]. These PWM techniques have different characteristics in terms of voltage utilization, harmonic suppression and switching frequency, suitable for different applications. Among these options, CB PWM is the simplest one to implement, which directly generates duty cycles for the switches from reference voltage vector, instead of sector identification and extensive numeric calculations of the switching period. Moreover, this method reduces total computation time of the controller, which in turn allows the system switching frequency to increase.

Int J Appl Power Eng, Vol. 8, No. 3, December 2019: 277 - 286 


\section{SIMULATION RESULTS}

To verify the merits of proposed 3P/3L NPC qZSI topology, a comprehensive simulation study is performed in MATLAB Simulink environment. The simulation and experimental parameters are shown in Table 1.

Table 1. Parameters Used in Simulation and Experiment

\begin{tabular}{|c|c|}
\hline Parameter & Value \\
\hline Input Voltage, $\mathrm{V}_{\text {in }}$ & $12 \mathrm{~V}$ \\
\hline Quasi Z-source inductors $\left(\mathrm{L}_{1}=\mathrm{L}_{2}=\mathrm{L}_{3}=\mathrm{L}_{4}\right)$ & $2 \mathrm{mH}$ \\
\hline Quasi Z-source capacitors $\left(\mathrm{C}_{1}=\mathrm{C}_{2}=\mathrm{C}_{3}=\mathrm{C}_{4}\right)$ & $2200 \mu \mathrm{F}$ \\
\hline Inverter side inductor, $\mathrm{L}_{\mathrm{inv}}$ & $2 \mathrm{mH}$ \\
\hline $\begin{array}{l}\text { Load side inductor, } \mathrm{L}_{\mathrm{grid}} \\
\text { Load side capacitor, } \mathrm{C}_{\mathrm{f}}\end{array}$ & $\begin{array}{c}2 \mathrm{mH} \\
0.22 \mu \mathrm{F}\end{array}$ \\
\hline Three-phase resistance load, $\mathrm{R}$ & $10 \mathrm{k} \Omega, 10 \mathrm{~W}$ \\
\hline Carrier frequency (fs) & $2.5 \mathrm{kHz}$ \\
\hline Modulating signal frequency (fm). & $50 \mathrm{~Hz}$ \\
\hline
\end{tabular}

LCL filter is employed to reduce the ripple which appears across the load terminals. The powered inverter is then terminated using a simple three phase resistance load for testing. Carrier frequency of $2.5 \mathrm{kHz}$ has been used to generate PWM gate signals fed to the switches. Modulating signal frequency has been taken same as the frequency of required output $\mathrm{AC}$ voltage. The shoot through duty ratio ' $D_{\mathrm{o}}$ ' and modulation index ' $M$ ' has been chosen as 0.1 and 0.9 respectively to realize the boost factor $\mathrm{B}$ of value 2 , where the output phase voltage, $\mathrm{V}_{\text {out }}$ reaches a value of $24 \mathrm{~V}$ (AC) from the input DC supply of $12 \mathrm{~V}$. Figure 4 shows the input DC voltage of value $12 \mathrm{~V}$ and boosted DC voltage having a peak value of $28 \mathrm{~V}$ which appear across the dc link. Figure 5 depicts boosted DC voltage of equal values in the range of $14 \mathrm{~V}$ obtained in the upper and lower legs due to quasi $\mathrm{Z}$ network. It is observed that the neutral point voltage is balanced in both the legs.
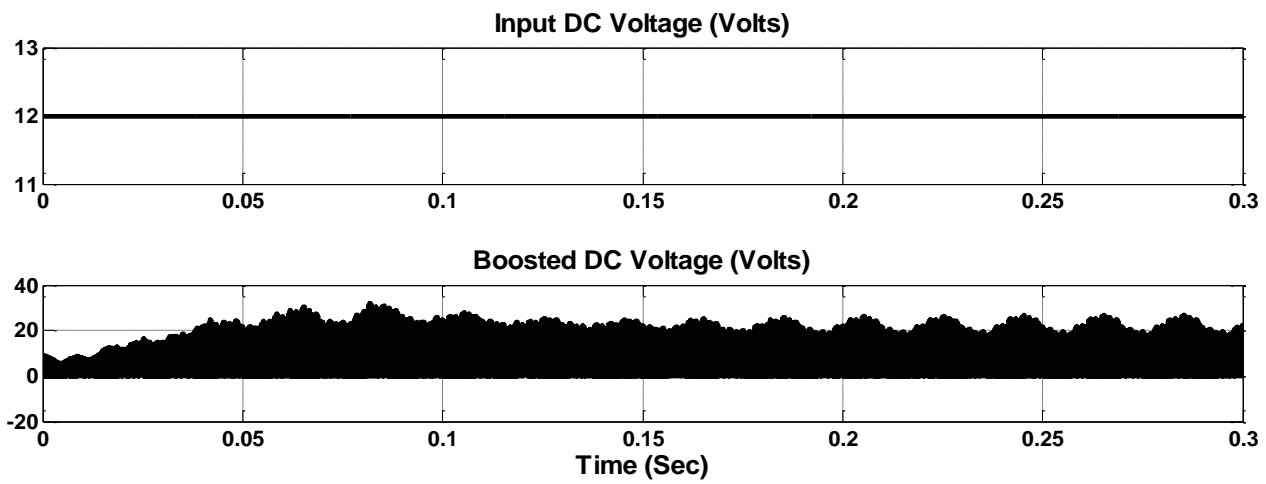

Figure 4. Input DC Voltage and boosted DC voltages
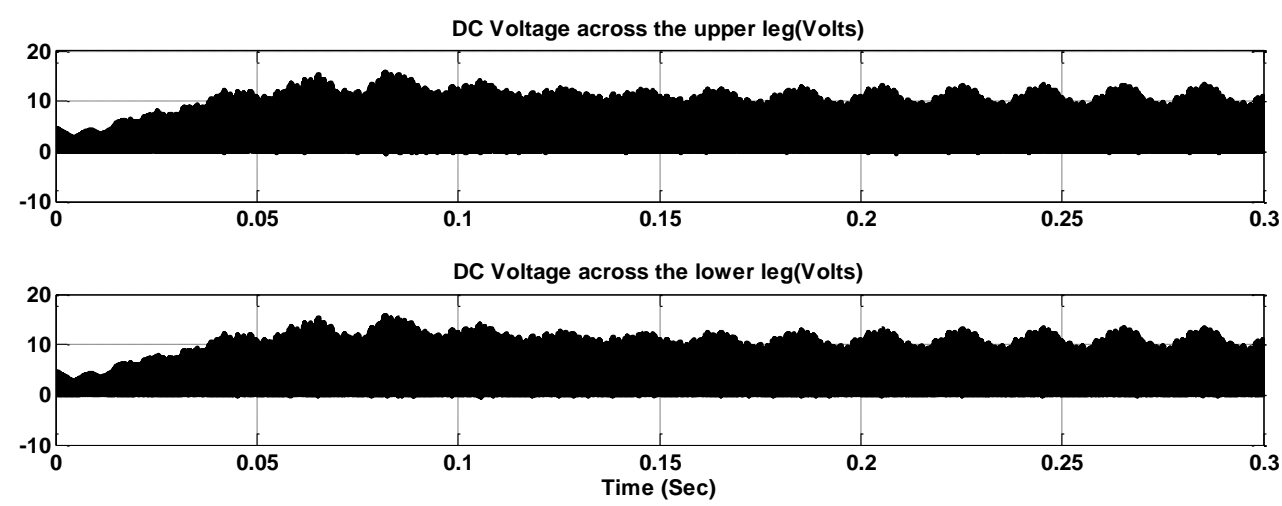

Figure 5. Boosted DC voltages of the quasi $\mathrm{Z}$ network obtained in the upper and lower legs 
Performing simulation, voltage developed across the capacitors has been found to be same i.e. $\left(\mathrm{V}_{\mathrm{cl}}=\mathrm{V}_{\mathrm{c} 2=} \mathrm{V}_{\mathrm{c} 3=} \mathrm{V}_{\mathrm{c} 4=1.77} \mathrm{~V}\right)$ with negligible ripple and input current is continuous with the value of $\left(\mathrm{I}_{\mathrm{L} 1}=\mathrm{I}_{\mathrm{L} 2}=\mathrm{I}_{\mathrm{L} 3}=\mathrm{I}_{\mathrm{L} 4=} 7.99 \mathrm{~A}\right)$. The proposed 3P/3L NPC qZSI topology can greatly reduce the $\mathrm{Z}$ source network capacitor voltage stress and inductor start current as mentioned above. To further inhibit the start inrush current, a soft start strategy can be applied which increases $D_{0}$ from 0 gradually at startup. Figure 6 and 7 shows current through the inductors $\left(\mathrm{L}_{1} \& \mathrm{~L}_{2}\right)$ and voltage across the capacitors $\left(\mathrm{C}_{1} \& \mathrm{C}_{2}\right)$ of the upper quasi $\mathrm{Z}$ network and current through the inductors $\left(\mathrm{L}_{3} \& \mathrm{~L}_{4}\right)$ and voltage across the capacitors $\left(\mathrm{C}_{3} \& \mathrm{C}_{4}\right)$ of the lower quasi $\mathrm{Z}$ network respectively.
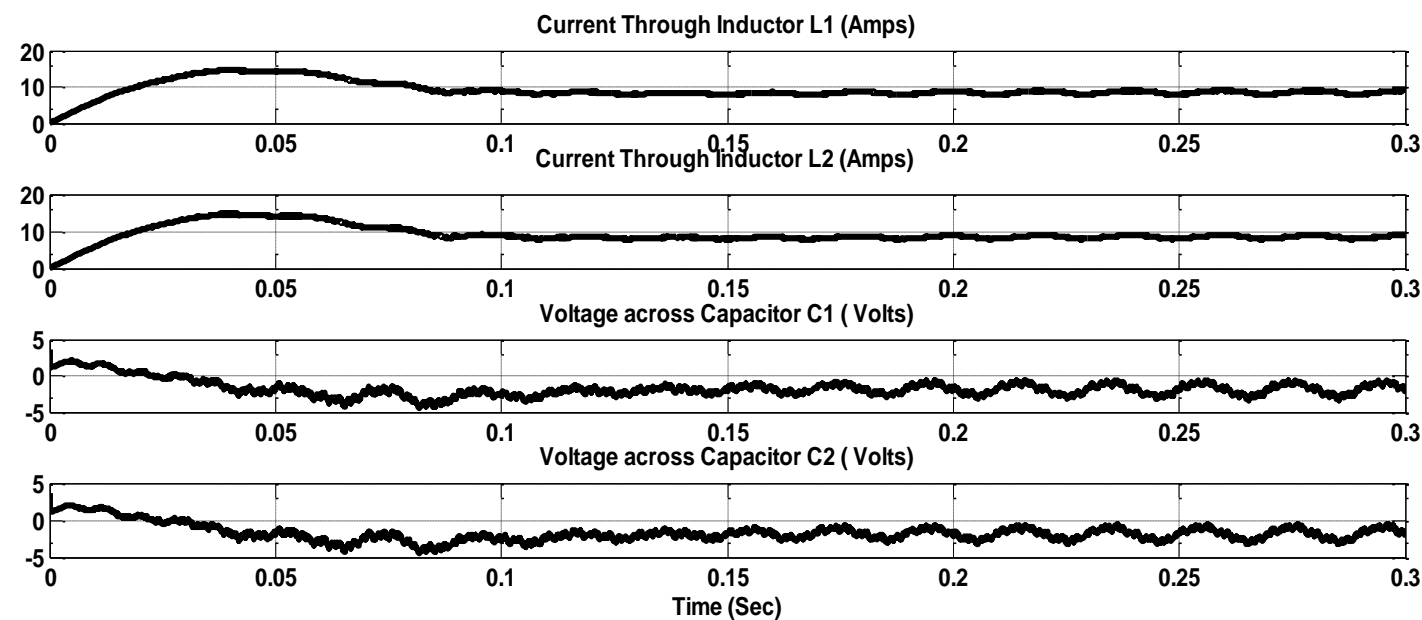

Figure 6. Current through the inductors $\left(\mathrm{L}_{1} \& \mathrm{~L}_{2}\right)$ and voltage across the capacitors $\left(\mathrm{C}_{1} \& \mathrm{C}_{2}\right)$ of the upper quasi $\mathrm{Z}$ network

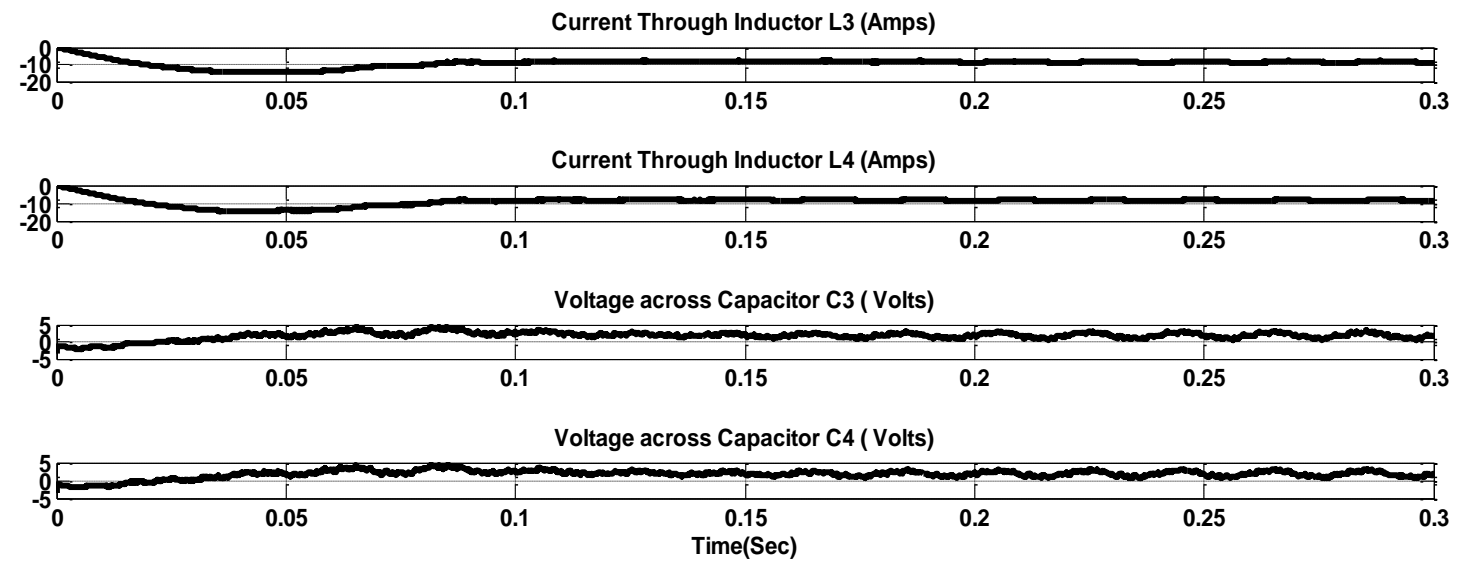

Figure 7. Current through the inductors $\left(\mathrm{L}_{3} \& \mathrm{~L}_{4}\right)$ and voltage across the capacitors $\left(\mathrm{C}_{3} \& \mathrm{C}_{4}\right)$ of the lower quasi $\mathrm{Z}$ network

The simulation results of phase voltage $\left(V_{\mathrm{xn}}\right)$ (i.e. voltage between point ' $\mathrm{X}=\mathrm{R}, \mathrm{Y}, \mathrm{B}$ ' and ' $\mathrm{n}$ ' shown in Figure 8). It is observed that a balanced boost three level phase voltage $\left(V_{\mathrm{xn}}\right)$ of value nearly $24 \mathrm{~V}$ has been achieved across the resistive load. The phase voltage and phase current waveform has been shown, where it has been observed that load is drawing a balanced three phase current. The input current is continuous and voltage across the DC link is uniform, and load voltage is purely sinusoidal which makes the proposed inverter suitable for photovoltaic system. The phase voltages and its corresponding total harmonics distortion (THD) of the load are observed from start time $0 \mathrm{sec}$ to complete 15 cycles of the simulation FFT window. The corresponding values are given to exhibit the performance of the inverter. (for phase $\mathrm{A}, \mathrm{V}_{\text {out }}=24.26 \mathrm{~V}$, $\mathrm{V}_{\mathrm{THD}}=2.20 \%$, phase $\mathrm{B}, \mathrm{V}_{\text {out }}=24.68 \mathrm{~V}, \mathrm{~V}_{\mathrm{THD}}=2.64 \%$ and phase $\left.\mathrm{C}, \mathrm{V}_{\text {out }}=25.12 \mathrm{~V}, \mathrm{~V}_{\mathrm{THD}}=3.20 \%\right)$. 

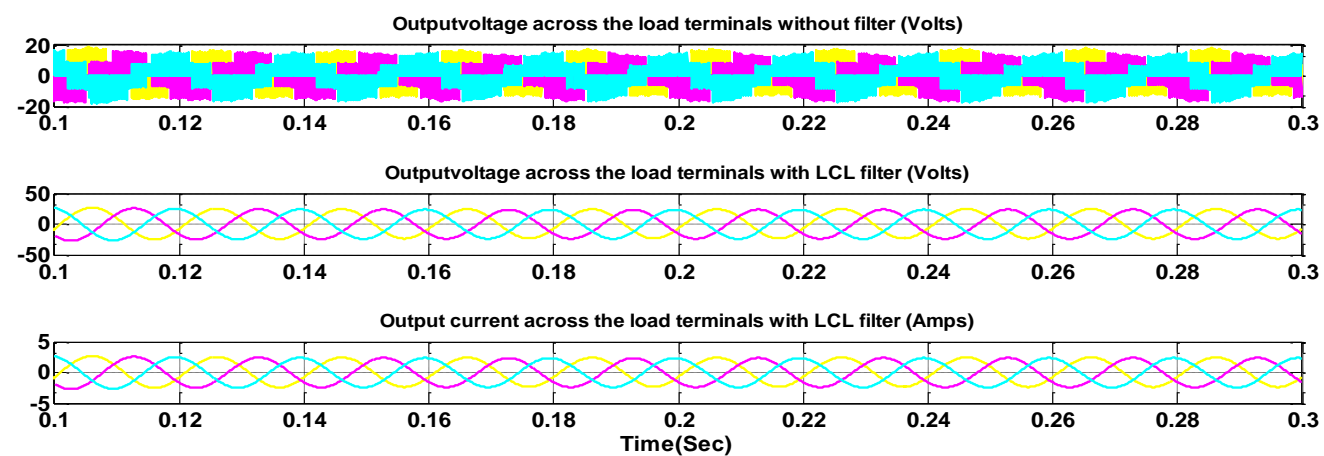

Figure 8. Simulated output AC voltage and AC current obtained across the load terminals with and without LCL filter

\section{EXPERIMENTAL RESULTS}

The proposed inverter is validated experimentally by developing a laboratory prototype, as shown in Figure 9. A three phase three level neutral point clamped quasi $\mathrm{Z}$ source inverter has been built and tested to validate its performance. The circuit parameters are given in Table 1 . Twelve no.s of $8 \mathrm{~A}, 500 \mathrm{~V}, 0.850 \Omega, \mathrm{N}$ channel power MOSFET of type IRF 840 (TO-220AB package) and 6 No.s of clamping diodes of type IN4007 (DO-204AL) are employed. The controller is implemented using Arduino Uno, ATmega328 real-time controller board, which has 14 digital input/output pins (of which 6 can be used as PWM outputs), 6 analog inputs, a $16 \mathrm{MHz}$ crystal oscillator, SRAM $2 \mathrm{~KB}$, EEPROM $1 \mathrm{~KB}$, flash memory $32 \mathrm{~KB}$, a USB connection, a power jack, an ICSP header, and a reset button. The sampling time of the controller has been set to $20 \mu \mathrm{s}$.

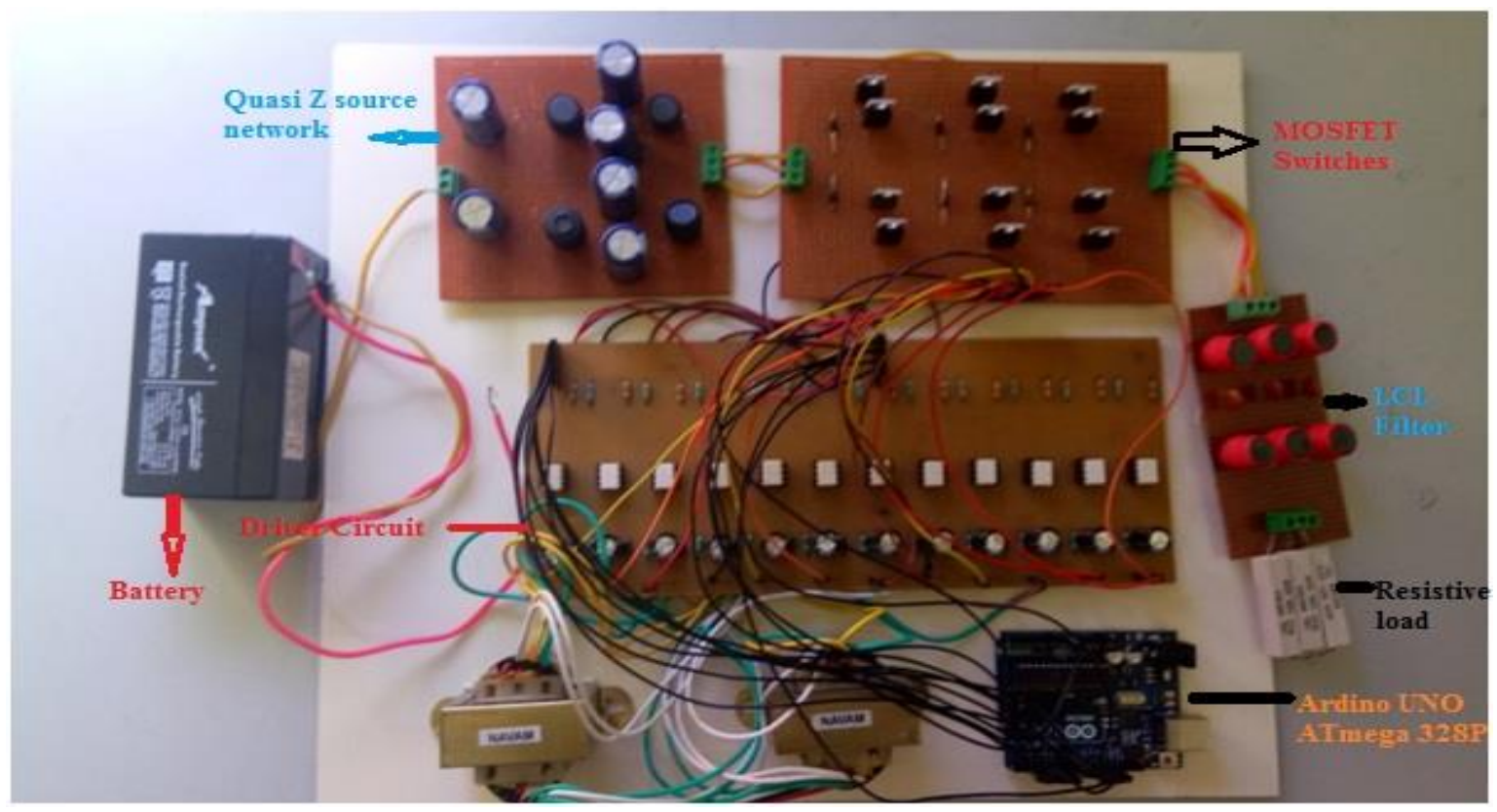

Figure 9. Experimental prototype of the proposed three phase three level neutral point clamped quasi $\mathrm{Z}$ source inverter

For experimental validation, a laboratory prototype has been developed for 12 volts DC input and 24 volts (r.m.s) output phase voltage $(\mathrm{Vph})$ are obtained during normal operation of the inverter in carrier based switching algorithm, where its performance can be viewed in terms of voltage waveforms, shown in Figure 10 and Figure 11.50 Watts resistive load has been connected to the inverter. Inductors and capacitors have been chosen same as taken in simulation. PWM signals have been generated using Arduino Uno, ATmega328. TLP250 and SN5401 ICs have been used as gate driver circuit and buffer circuit respectively. It should be mentioned that the inverter operates at low switching frequency of $2.5 \mathrm{kHz}$ which reduces the 
system switching losses, ensures high power factor, low THD grid currents, robustness and operation at constant switching frequency which makes it to be a good candidate in interfacing renewable energy sources like photovoltaic systems. The balancing of the DC capacitors voltages is also accomplished. Due to the associated non idealities, it can be realized that the voltage amplitudes of experimental results are less than the theoretical values. Performance of this proposed inverter can be made better by taking lower inductor current ripple into consideration, relaxing on capacitor voltage ripple based on the allowable ripple content. The efficiency of the proposed inverter is little low because of additional switches and diodes which introduces switching losses. But, use of less number of passive elements in the inverter reduces system volume and weight.

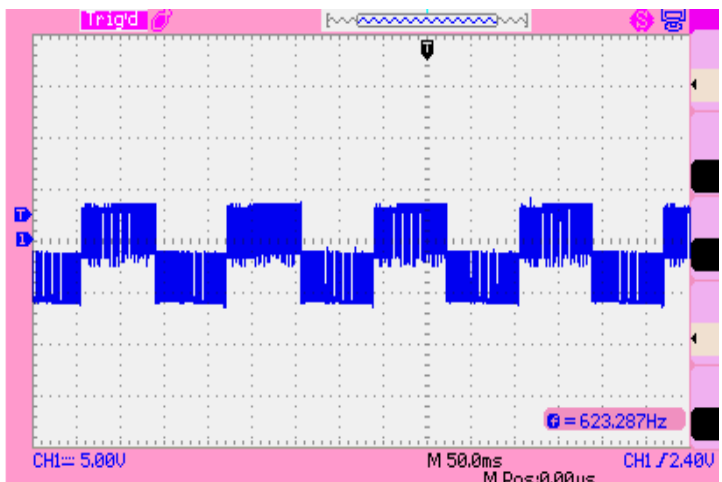

(a)

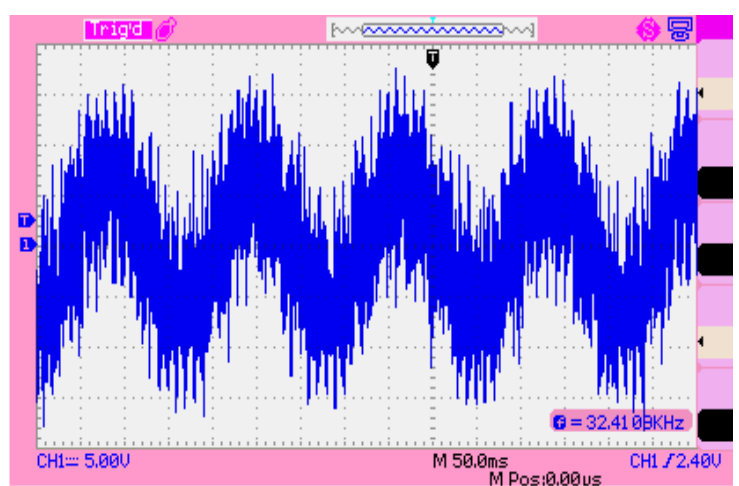

(b)

Figure 10 Phase voltage waveforms observed at the load: (a) before filter, (b) after LCL filter

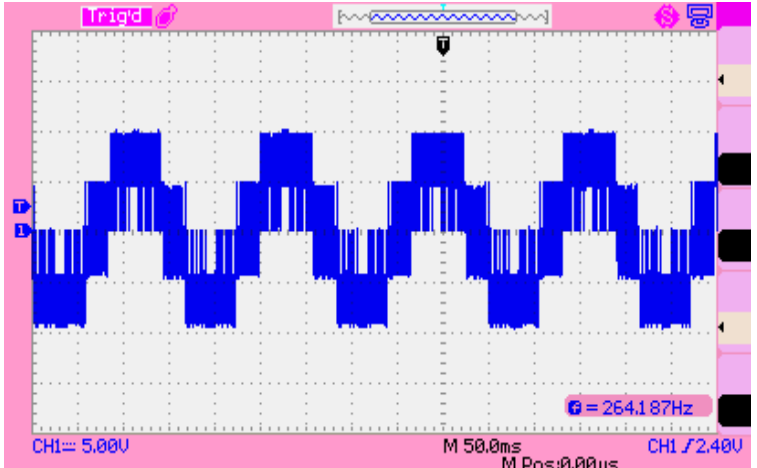

(a)

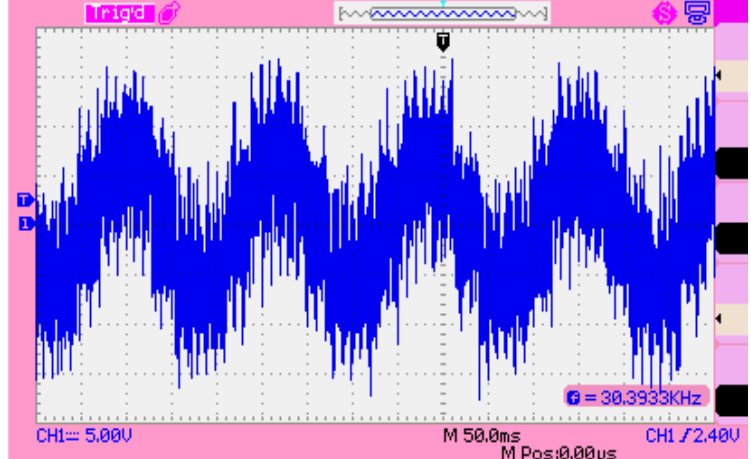

(b)

Figure 11. Line voltage waveforms observed at the load: (a) before filter, (b) after LCL filter

\section{CONCLUSION}

A new 3P/3L NPC qZSI topology is proposed in this paper. The proposed inverter is able to boost the input DC voltage and give required three level AC output in a single stage unlike conventional NPC VSI, by utilizing shoot through state. The steady state operation of the inverter is discussed and voltage gain function is derived. Both simulation and experimented results are presented to validate its effectiveness and practicality which shows that this topology can produce continuous current, voltage with better harmonic performance, significant reduction in total harmonic distortion, $\mathrm{Z}$ source network capacitor voltage stress and also inhibit the start inrush current and better neutral point potential balancing with enhanced system reliability. This proposed inverter is well suited for photovoltaic systems. 


\section{ACKNOWLEDGEMENTS}

This work is part of the Central Power Research Institute Project, A Government of India Society, Ministry of Power, Bangalore (Project Code: RSOP/2015/DG/6/15122015). The support of this organization is gratefully acknowledged.

\section{REFERENCES}

[1] Jagabar Sathik Mohd.Ali, Vijayakumar Krishnaswamy, "An assessment of recent multilevel inverter topologies with reduced power electronics components for renewable applications," Renewable and Sustainable Energy Reviews, vol. 82, pp. no. 3379-3399, 2018.

[2] Peeyush Kala, Sudha Arora, "A comprehensive study of classical and hybrid multilevel inverter topologies for renewable energy applications," Renewable and Sustainable Energy Reviews, vol. 76, pp. no. 905-931, 2017.

[3] V. Saravanan, M. Aravindan, V. Balaji, M. Arumugam, "Status of Solar Photovoltaic Systems in India" in National Seminar on Emerging Energy Scenario in India - Issues, Challenges and Way Forward, (NLCIL - National Seminar 2018), Learning and Development Center, NLC INDIA LIMITED (Formerly Neyveli Lignite Corporation Limited), Block - 20, Neyveli, Tamilnadu. (pg. no.189 to 198, Renewable Energy Section), 20 - 22 January 2018.

[4] Nor Shahida Hasan, Norzanah Rosmin, Dygku. Asmanissa Awg. Osman, Aede Hatib Musta'amal@Jamal, "Reviews on multilevel converter and modulation techniques," Renewable and Sustainable Energy Reviews, vol. 80, pp. no. 163-174, 2017.

[5] Jose Rodriguez, Steffen Bernet, Peter K. Steimer, Ignacio E. Lizama, "A survey on Neutral Point Clamped Inverters," IEEE Transactions on Industrial Electronics, vol. 57, no. 7, 2219 - 2230, July 2010.

[6] Ebrahim babaei, Hitham Abu-Rub, Hiralal M. Suryawanshi, "Z Source Converters: Topologies, Modulation Techniques, and Application-Part I," IEEE Transactions on Industrial Electronics, vol.65, no. 6, pp. 5092 - 5095, 2018.

[7] Yam P. Siwakoti, Fang Zheng Peng, Frede Blaabjerg, Poh Chiang Loh, and Graham E. Town, "Impedance Source Networks for Electric Power Conversion Part I: A Topological Review," IEEE Transactions on Power Electronics, vol. 30, no. 2, pp. 699 - 716, 2015.

[8] Yam P. Siwakoti, Fang Zheng Peng,Frede Blaabjerg,Poh Chiang Loh, Graham E. Town, Shuitao Yang, "Impedance Source Networks for Electric Power Conversion Part II: Review of Control and Modulation Techniques," IEEE Transactions on Power Electronics, vol. 30, no. 4, pp. 1887-1906, 2015.

[9] Negar Noroozi, Mohammad Reza Zolghadri, "Three Phase Quasi Z Source Inverter with Constant Common Mode Voltage for Photovoltaic Application," IEEE Transactions on Industrial Electronics, vol.65, no. 6, pp. 4790 - 4798, 2018.

[10] Yanjun Shi, Thierry Kayiranga, Yuan Li, Hui Li, "Exploring the LCL Characteristics in GaN based Single L Quasi Z Source Grid Tied Inverters," IEEE Transactions on Industrial Electronics, vol. 64, no. 10, pp. 7758-7768, 2017.

[11] Ahmad Syed, Tara Kalyani Sandipamu, Freddy Tan Kheng Suan, "High-efficiency neutral point clamped transformerless MOSFET inverter for photovoltaic applications," IET Power Electronics, vol. 11, no. 2, pp. 246-252, 2018.

[12] Xibo Yuan, Niall Oswald, and Philip Mellor, "Super junction MOSFETs in Voltage-Source Three Level Converters: Experimental Investigation of Dynamic Behavior and Switching Losses," IEEE Transactions on Power Electronics, vol. 30, no. 12, pp. 6495-6501, 2015.

[13] Neville McNeill, Xibo Yuan, and Philip Anthony, "High Efficiency NPC Multilevel Converter Using Super Junction MOSFETs," IEEE Transactions on Industrial Electronics, vol. 63, no. 1, pp. 23 - 37, 2016.

[14] Husev, O., Roncero-Clemente, C., Romero-Cadava, E., and Vinnikov, D, "Single phase three level neutral point clamped quasi Z source inverter," IET Power Electronics, vol. 8, no. 1, pp. 1-10, 2015.

[15] Deqing Yu, Qiming Cheng, Jie Gao, Fengren Tan, Yu Zhang, "Three level neutral point clamped quasi Z source inverter with reduced Z source capacitor voltage," Electronics Letters, vol. 53, no. 3, pp. 185-187, 2017.

[16] Oleksandr Husev,Carlos Roncero Clemente, Enrique Romero Cadaval, Dmitri Vinnikov, Tanel Jalakas, "Three level three phase quasi $\mathrm{Z}$ source neutral point clamped inverter with novel modulation technique for photovoltaic application," Electric Power Systems Research, vol. 130, pp. 10-21, 2016.

[17] Poh Chiang Loh, Blaabjerg F,Chow Pang Wong, "Comparative evaluation of pulse width modulation strategies for Z Source Neutral Point Clamped Inverter," IEEE Transactions on Power Electronics, vol. 22, no. 3, pp. 1005 1013, 2007.

[18] Poh Chiang Loh, Feng Gao, Blaabjerg, F, Shi Yun Charmaine Feng, Kong Ngai Jamies Soon, "Pulse width Modulated Z Source Neutral Point Clamped Inverter," IEEE Transactions on Industry Applications, vol. 43, no. 5, pp. 1295-1308, 2007.

[19] Yuan Yao, Longyun Kang, Zhi Zhang and Yuanbin Feng, "Two stage carrier based PWM to mitigate neutral point potential oscillation in three-level inverters," Electronics Letters, vol. 53 no. 20, pp. 1377-1379, 2017.

[20] Abhijit Choudhury, Pragasen Pillay, Sheldon S. Williamson, "Performance Comparison Study of Space Vector and Modified Carrier Based PWM Techniques for a Three Level Neutral Point Clamped Traction Inverter Drive ", IEEE Journal of Emerging and Selected Topics in Power Electronics," vol. 4, no. 3, pp. 1064-1076, 2016.

[21] Santu Kr. Giri, Sibaprasad Chakrabarti, Subrata Banerjee, Chandan Chakraborty, "A Carrier Based PWM Scheme for Neutral Point Voltage Balancing in Three Level Inverter Extending to Full Power Factor Range," IEEE Transactions on Industrial Electronics," vol. 64, no. 3, pp. 1873-1883, 2017. 
[22] R. Palanisamy1, K. Vijayakumar, "Maximum Boost Control for 7-level Z-Source Cascaded H-Bridge Inverter," International Journal of Power Electronics and Drive System, vol. 8, no. 2, pp. 739-746, June 2017.

[23] Yuyao He, Yuhao Xu, Jinping Chen, "New Space Vector Modulation Strategies to Reduce Inductor Current Ripple of Z Source Inverter," IEEE Transactions on Power Electronics, vol. 33, no. 3, pp. 2643 - 2654, 2018.

[24] T. Porselvi, K. Deepa, R. Muthu, "FPGA Based Selective Harmonic Elimination Technique for Multilevel Inverter," International Journal of Power Electronics and Drive System, vol. 9, no. 1, pp. 166-173, March 2018.

[25] Ahmed Abdelhakim, Pooya Davari, Frede Blaabjerg, Paolo Mattavelli, "Switching Loss Reduction in the Three Phase Quasi Z Source Inverters Utilizing Modified Space Vector Modulation Strategies," IEEE Transactions on Power Electronics, vol. 33, no. 5, pp. 4045-4060, 2018.

[26] Wei Chen, Wenkai Dai, Zhiqiang Wang, Guozheng Zhang, Yan Yan, Changliang Xia, "Optimal space vector pulse width modulation strategy of neutral point clamped three-level inverter for output current ripple reduction," IET Power Electronics, vol. 10, no. 12, pp. 1638-1646, 2017.

[27] Gnana Prakash M, Balamurugan M, Umashankar S, "A New Multilevel Inverter with Reduced Number of Switches," International Journal of Power Electronics and Drive System, vol. 5, no. 1, pp. 63-70, July 2014.

[28] Xiao-hua Zhang and Wen-kai Yue, "Neutral point potential balance algorithm for three level NPC inverter based on SHEPWM," Electronics Letters, vol. 53, no. 23 pp. 1542-1544, 2017.

[29] Suresh Natarajan, R. Samuel Rajesh Babu, "Comparison of Cascaded H-bridge Inverters for Harmonic Mitigation Considering Various Loads," International Journal of Power Electronics and Drive System, vol. 8, no. 1, pp. 10 19, March 2017.

[30] Cungang $\mathrm{Hu}$, Grahame Holmes, Weixiang Shen, Xinghuo Yu, Qunjing Wang, Fanglin Luo, "Neutral point potential balancing control strategy of three level active NPC inverter based on SHEPWM," IET Power Electronics, vol. 10, no. 14, pp. 1943-1950, 2017.

[31] K. J. Pratheesh, G. Jagadanand, and Rijil Ramchand, "A Generalized Switch Matrix Based Space Vector Modulation Technique Using the Nearest Level Modulation Concept for Neutral Point Clamped Multilevel Inverters," IEEE Transactions on Industrial Electronics, vol. 65, no. 6, pp. 4542 - 4552, 2018.

[32] Li Kai, Jiancheng Zhao, Wenjie Wu, Mengshu Li, Lan Ma, Gang Zhang, "Performance analysis of zero common mode voltage pulse width modulation techniques for three level neutral point clamped inverters," IET Power Electronics, vol. 9, no.14, pp. 2654-2664, 2016.

[33] A. Sangari, R Umamaheswari "Analysis of impedance source inverter topologies for grid integration of PV inverters," International Journal of Power Electronics and Drive System, vol. 6, pp. 797-807, 2015.

[34] Iraide López, Salvador Ceballos, Josep Pou, Jordi Zaragoza, Jon Andreu, Iñigo Kortabarria, Vassilios G. Agelidis, "Modulation Strategy for Multiphase Neutral Point Clamped Converters," IEEE Transactions on Power Electronics, vol. 31, no. 2, pp. 928-941, 2016.

[35] Fadia Sebaaly, Hani Vahedi, Hadi Y. Kanaan, Nazih Moubayed, Kamal Al-Haddad, "Design and Implementation of Space Vector Modulation Based Sliding Mode Control for Grid Connected 3L NPC Inverter," IEEE Transactions on Industrial Electronics, vol. 63, no. 12, pp. 7854-7863, 2016.

[36] R. Malathi, M. Rathinakumar, "Comparison of sine and space vector modulated embedded Z source inverter fed three phase induction motor drive system, "International Journal of Power Electronics and Drive System, vol.7, pp.1240-1251, 2016. 